\title{
The Effectiveness of Lemongrass Oil Against Brown planthopper Nilaparvata lugens Stal. (Hemiptera: Delphacidae) on Rice Plant
}

\author{
Toto Himawan*, Rina Rachmawati, Eka Putri Rifandani \\ Plant Protection Department, Faculty of Agriculture, University of Brawijaya Jl. Veteran, Malang 65145, East Java, Indonesia
}

Submitted 25 August 2020 Accepted 29 October 2020

Corresponding author Toto Himawan; totohimawan@yahoo.co.id

\section{ABSTRACT}

Rice (Oryza sativa) is the primary food crop in the world. The use of natural pesticides made from essential plants has begun to be developed because it is useful in controlling some plant pests. This study aimed to investigate lemongrass oil's effectiveness in controlling brown planthopper pests in rice plants. This study consist of five concentrations using lemongrass oil and sterile distilled water as control was repeated three times. The highest mortality of brown planthopper was found at $1.6 \%$ concentration $(100 \%)$, while the lowest mortality was $0.1 \%$ concentration $(26.66 \%)$. The lemongrass oil can be used to control brown planthoppers because of the $\mathrm{LC}_{50}$ value at a concentration of $8233.34 \mathrm{ppm}$ $(0.8 \%)$ and $L_{50}$ at 6 HAT.

Keywords: Mortality; Cymbopogon citratus; $\mathrm{LT}_{50}$; $\mathrm{LC}_{50}$; brown planthopper

\section{INTRODUCTION}

Rice (Oryza sativa) is the primary food crop in the world. Nearly $40 \%$ of the world population consumes rice as the primary staple food (Dunna and Roy, 2013). However, there are many problems in increasing rice production, including pests and diseases of rice plants. One of the pests that cause rice production losses is the brown planthopper's (Nilaparvata lugens Stal.) attack (Sandhu and Sarao, 2020). Currently, brown planthopper has become a global pest (Nagella, 2014). This pest is tough to control because it is easy to adapt, and it can form new biotypes (Siegwart et al., 2015). Brown planthopper damages rice plants by sucking rice stem cells' liquid and causes plant growth to be stunted. If the population is high, it can cause rice plants to become dry and burning symptoms (AB Ghaffar et al., 2011). To reduce economic losses due to pest attacks, farmers generally still depend on synthetic pesticides. The use of pesticides that are not appropriate can cause pest problems and pest outbreaks (Ndakidemi et al., 2016).

Natural pesticides made from plants' essential oil have begun to be developed because it is useful in controlling some plant pests. .Indonesia is a biodiversity country with various types of plants that can be used as essential oils, including lemongrass (Cymbopogon nardus L.). In previous research, lemongrass oil has insecticidal and repellent properties against Helopeltis antonii and Chinese pepper Dasynus piperis (Laba, 2016; Mardiningsih and Ma' mun, 2018). Lemongrass oil is also insecticidal against the Musca domestca house fly (Sandhu and Sarao, 2020). The three main components of citronella oil, namely citronellal, citronellol, and geraniol, are used in large quantities in the flavor industry (Eden et al., 2018). 
The distillation of $C$. nardus (L.) can be obtained by an essential oil called oleum citronella, while the active ingredients that are deadly to pests are citronellal and geraniol (Pinheiro et al., 2013). This study aimed to investigate lemongrass oil's effectiveness in controlling brown planthopper pests in rice plants.

\section{MATERIALS AND METHODS}

This research was conducted from February until July 2016 at the Laboratory of Toxicology and Greenhouses, Department of Pests and Plant Diseases, Faculty of Agriculture, Universitas Brawijaya. This study consisted of 5 treatments of different concentrations $(0.1 . \%, 0.2 \%, 0.4 \%, 0.8 \%$, and $1.6 \%$ ) and sterile distilled water as a control, and all treatment was repeated three times. The application of citronella oil was carried out by the insect spray method on plants. Twenty nymphs of brown planthopper were infested into rice plants in plastic mica cages.

\section{Insect test rearing}

Rice plants were planted in greenhouses. Rice plants were planted in plastic trays $(d=15 \mathrm{~cm} \times 20$ $\mathrm{cm})$ and were put in a gauze cage $(30 \mathrm{~cm} \times 30 \mathrm{~cm}$ $x 100 \mathrm{~cm}$ ) to serve as a diet for adults and nymphs of brown planthoppers. The third instar planthopper nymphs were used in this study and kept in gauze cages.

\section{Preparation of Rice Plants for Treatment}

The rice plants' preparation for treatment was carried out in a greenhouse by sowing rice seeds in plastic trays $(15 \mathrm{~cm} \times 20 \mathrm{~cm})$. Rice seeds that 15 days old were transferred to plastic pots $(d=6 \mathrm{~cm}$ and $t=10 \mathrm{~cm})$. In each pot, three rice seeds were planted. After the rice plant was 30 days old (15 days after transplanting), it was used for treatment.

\section{Lemongrass Oil Extraction}

Lemongrass oil was obtained from the steam distillation of lemongrass leaves at the Universitas Brawijaya Essential Oil Center Unit in Kesamben Village, Blitar Regency. The purification of lemongrass using MgSO4 until saturated then separated. The essential oil obtained was used for the saponification process. The material used for the saponification of lemongrass oil was Teepol. Teepol (surfactant) was mixed with pure lemongrass oil until a mixture is obtained that can blend with the ratio of oil and teepol 1: 3 .

\section{Mortality of Brown Planthopper}

Mortality testing was carried out using lemongrass extract and distilled water as controls. The application was carried out by the insect spray method on plants (Molide et al. 2011). As many as 20 third instar test insects were infested into rice plants in mylar confinement, then sprayed with lemongrass extract evenly. The concentrations tested for the experimental insect spray method on plants were $0 \%, 0.1 \%, 0.2 \%, 0.4 \%, 0.8 \%, 1.6 \%$ with a spray volume of $10 \mathrm{ml} /$ treatment. Observation of the tested insects' nymph mortality was calculated at $3,6,9,12$, and 48 days after treatment (DAT). The $\mathrm{LC}_{50}$ was calculated the mortality from the lowest concentration of $0 \%$ to the highest concentration of $1.6 \%$. The $\mathrm{LT}_{50}$ for each treatment was calculated from 3 to 24 hours after treatment (HAT).

\section{Data Analysis}

The percentage of planthopper mortality was analyzed by using Probit Hsin Chi. The percentage of the mortality rate was calculated using the following formula: 
Table 1. The average mortality of brown planthopper

\begin{tabular}{cccccc}
\hline Concentrations & \multicolumn{5}{c}{ Mortality (\%) } \\
\cline { 2 - 6 } & 3 HAT & 6 HAT & 9 HAT & 12 HAT & 24 HAT \\
\hline $0.1 \%$ & 3.33 & 10.00 & 23.33 & 21.66 & 26.66 \\
$0.2 \%$ & 16.66 & 30.00 & 38.33 & 50.00 & 61.66 \\
$0.4 \%$ & 23.33 & 38.33 & 48.33 & 60.00 & 71.66 \\
$0.8 \%$ & 35.00 & 53.33 & 66.66 & 81.66 & 90.00 \\
$1.6 \%$ & 93.33 & 100.00 & 100.00 & 100.00 & 100.00 \\
\hline
\end{tabular}

Note: HAT: Hours After Treatment

$$
P=X / Y \times 100 \%
$$

Where $P$ is the percentage of the death rate, $X$ is the nymph that dies, $Y$ is the total number of nymphs observed.

\section{RESULTS AND DISCUSSIONS}

\section{Mortality of brown planthopper}

The results showed that the highest mortality of brown planthopper was found at $1.6 \%$ concentration $(100 \%)$, while the lowest mortality was $0.1 \%$ concentration $(26.66 \%)$ at 24 HAT (Table 1$)$. In the 24 HAT observations, all the treatments showed a different effect on mortality. It demonstrated that lemongrass extract could kill brown planthoppers. The mechanism of pest death by lemongrass extract is by destroying the cell walls of the pests so that lemongrass oil will enter and spread throughout the body, and then this oil will damage the metabolic work of cells, which results in the pest's body experiencing a deficiency of $\mathrm{O}_{2}$ and $\mathrm{H}_{2} \mathrm{O}$ (dehydration) (Poonpaiboonpipat et al., 2013). Lemongrass oil at a concentration of $2,000 \mathrm{ppm}$ or equal to $0.2 \%$ was able to kill $H$. antonii $(91.62 \%$ mortality), while at a concentration of $4,000 \mathrm{ppm}$ or equal to $0.4 \%$, the mortality reached $100 \%$ after 6 HAT (Mardiningsih and Ma' mun, 2018). The treatment of lemongrass oil with $1.5 \%$ concentration against Plutella xylostella can cause $100 \%$ mortality of tested insects' initial population on the sixth day (Prasetyo et al., 2013).

The lemongrass oil causes brown planthopper symptoms, including; color changes, nymph's body becomes whitish-yellow, then the color changes again to brown, and the whole body turns black (dies) (Figure 1). Even at a relatively high concentration of essential oil formulations, it will cause marked symptoms such as starting to change skin color that fades to the test insects' death on a time scale between approximately 2-3 hours after treatment (Prasetyo et al., 2013).

The lemongrass oil causes brown planthopper symptoms, including; color changes, nymph's body becomes whitish-yellow, then the color changes again to brown, and the whole body turns black (dies) (Figure 1). Even at a relatively high concentration of essential oil formulations, it will cause
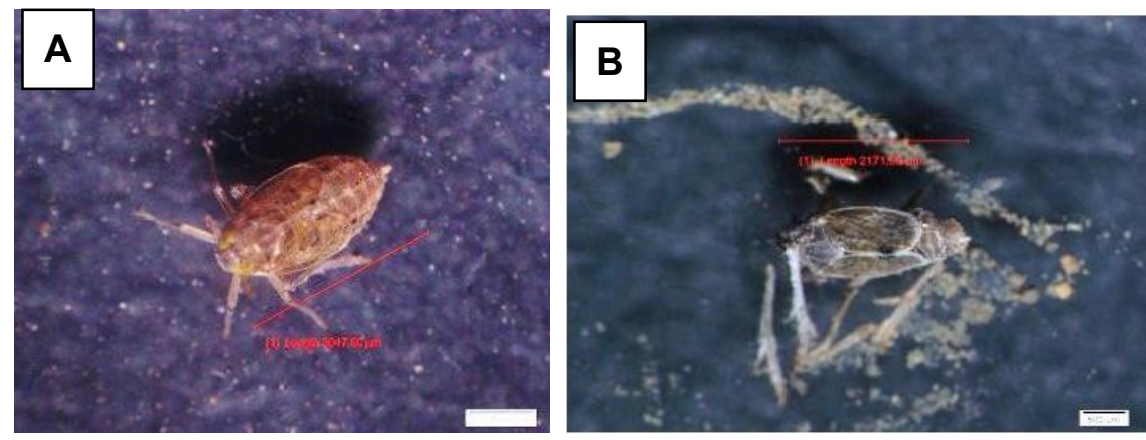

Figure 1. Healthy planthopper and dead planthopper at 48 HAT. 
Table 2. $L C_{50}$ and $L T_{50}$ value of lemongrass extract against brown planthopper

\begin{tabular}{lccccc} 
& \multirow{2}{*}{ Estimate } & Regression Equations & SE & \multicolumn{2}{c}{ Limits } \\
\cline { 5 - 6 } & & & & Lower & Upper \\
\hline $\mathrm{LC}_{50}(\mathrm{ppm})$ & 8233.34 & $\mathrm{y}=1.12 \mathrm{x}+0.57$ & 0.45 & 6865.54 & 10436.29 \\
$\mathrm{LT}_{50}$ (hour) & 6.02 & $\mathrm{y}=1.92 \mathrm{x}+3.49$ & 0.50 & 4.52 & 7.46 \\
\hline
\end{tabular}

Note: SE: Standard error

marked symptoms such as starting to change skin color that fades to the test insects' death on a time scale between approximately 2-3 hours after treatment (Prasetyo et al., 2013).

Lethal concentration $\left(\mathrm{LC}_{50}\right)$ and Lethal time $\left(\mathrm{LT}_{50}\right)$ of lemongrass against Brown Planthopper

The results showed that the lemongrass extract of $8233.34 \mathrm{ppm}(0.8 \%)$ at 6 HAT cause $50 \%$ mortality of brown planthopper. The regression equation shows that each addition to lemongrass's square concentration will cause mortality of $1.12 \%$ (Figure 2 ). In lemongrass extract in $0.2 \%$ concentration at 6 HAT was able to

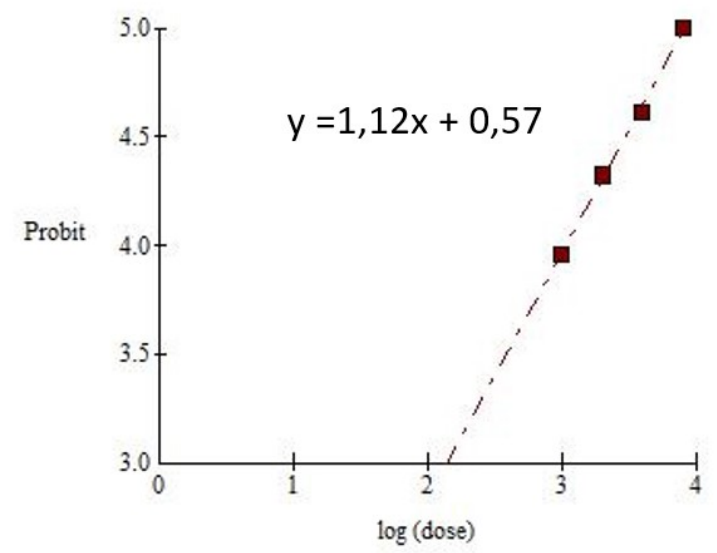

Figure 2. Relation of log dose (concentration) to the mortality of brown leafhoppers after application of lemongrass

cause brown planthopper mortality of $53.33 \%$. As reported in Nurmansyah (2016), the citronella oil concentration of $0.2 \%$ in 6 HAT has caused the mortality of $H$. Antonii of $91.62 \%$. The protective power of this citronella oil will increase as the concentration of citronella oil increases. Furthermore, lemongrass oil at a concentration of $2.5 \%$ can repel (Boonyuan et al., 2014).

\section{CONCLUSIONS}

The highest mortality of brown planthopper was found at $1.6 \%$ concentration $(100 \%)$, while the lowest mortality was $0.1 \%$ concentration (26.66\%). The lemongrass oil can be used to control brown planthoppers because of the $\mathrm{LC}_{50}$ value at a concentration of $8233.34 \mathrm{ppm}(0.8 \%)$ and $\mathrm{LT}_{50}$ at $6 \mathrm{HAT}$.

\section{REFERENCES}

Boonyuan, W., J. Grieco, M. Bangs, A. Prabaripai, S. Tantakom, et al. 2014. Excito-Repellency of Essential Oils against an Aedes aegypti (L.) Field Population in Thailand. J. Vector Ecol. 39. doi: 10.1111/j.1948-7134.2014.12077.x.

Dunna, V., and B. Roy. 2013. Rice (Oryza sativa L.). Breeding, Biotechnology and Seed Production of Field Crops. New India Publishing Agency. p. 52

Eden, W., D. Alighiri, E. Cahyono, K. Supardi, and N. Wijayati. 2018. Fractionation of Java Citronella Oil and Citronellal Purification by Batch Vacuum Fractional Distillation. IOP Conf. Ser. Mater. Sci. Eng. 349: 12067. doi: 10.1088/1757-899X/349/1/012067.

Ghaffar, M.B., J. Pritchard, and B. Ford-Lloyd. 2011. Brown Planthopper (N. lugens Stal) Feeding Behaviour on Rice Germplasm as an Indicator of Resistance. PLoS One 6: e22137. doi: 10.1371/journal.pone.0022137. 
Laba, I.W. 2016. Efektivitas Insektisida Minyak Serai Wangi Dan Cengkeh Terhadap Hama Pengisap Buah Lada (Dasynus piperis). Bul. Littro 24(1): 26-34. doi: 10.21082/ bullittro.v24n1.2013.\%p.

Nurmansyah. 2016. Efektivitas Serai Wangi Terhadap Hama Pengisap Buah Kakao Helopeltis Antonii. 22(2): 205-213. doi: 10.21082/ bullittro.v22n2.2011.\%p.

Mardiningsih, T., and NFN Ma' mun. 2018. The Effect of Essential Oil Formulas on Mortality and Oviposition Deterrent of Helopeltis antonii. Bul. Penelit. Tanam. Rempah dan Obat 28: 171 . doi: 10.21082/ bullittro.v28n2.2017.171-180.

Nagella, K. 2014. A Global Perspective of Rice Brown Planthopper Management $\square$--CropClimatic Requirement. Int. J. Mol. Zool. doi: 10.5376/ijmz.2014.04.0002.

Ndakidemi, B., K. Mtei, and P. Ndakidemi. 2016. Impacts of Synthetic and Botanical Pesticides on Beneficial Insects. Agric. Sci. 07: 364-372. doi: 10.4236/as.2016.76038.

Pinheiro, P.F., V.T. de Queiroz, V.M. Rondelli, A.V. Costa, T. de P. Marcelino, et al. 2013. Atividade inseticida do óleo essencial de capimcitronela sobre Frankliniella schultzei e Myzus persicae. Cienc. e Agrotecnologia 37(2): 138$144 . \quad$ doi: 10.1590/S141370542013000200004.

Poonpaiboonpipat, T., U. Pangnakorn, U. Suvunnamek, M. Teerarak, P. Charoenying, et al. 2013. Phytotoxic effects of essential oil from Cymbopogon citratus and its physiological mechanisms on barnyardgrass (Echinochloa crus-galli). Ind. Crops Prod. 41: 403-407. doi: 10.1016/j.indcrop.2012.04.057.

Prasetyo, H., I. Susila, and K. Sumiartha. 2013. Efikasi Minyak Atsiri Sereh Dapur (Cymbopogon citratus L.) terhadap Hama Ulat Daun Kubis (plutella xylostella L.) di Laboratorium. E-Jurnal Agroekoteknologi Trop. (Journal Trop. Agroecotechnology) 2(2): 99107.

Sandhu, R.K., and PS Sarao. 2020. Evaluation of antixenosis resistance in wild rice accessions against brown planthopper, Nilaparvata lugens (Stål). Int. J. Trop. Insect Sci. doi: 10.1007/s42690-020-00176-x.

Siegwart, M., B. Graillot, C. Blachere Lopez, S. Besse, M. Bardin, et al. 2015. Resistance to bio-insecticides or how to enhance their sustainability: a review. Front. Plant Sci. 6: 381. doi: 10.3389/fpls.2015.00381. 